\title{
Edward Topsell's The History of \\ Four-footed Beasts and Serpents
}

One of the more remarkable books in the Rare Book Collection at The University of Iowa is the liberally illustrated compendium of Elizabethan beliefs about animals, The History of Four-footed Beasts and Serpents, published in London in 1658. It is a large volume of over 1,100 folio-size pages comprising the second editions of three works which had been published separately at the beginning of the seventeenth century: Edward Topsell's The Historie of Fourefootid Beastes in 1607, his The Historie of Serpents in 1608, and Thomas Moffett's Insectorum sive Minimorum Animalium Theatrum in 1634. These three works were edited for the single-volume reissue of 1658 by John Rowland, M.D., who states on the title page that "the whole" has been "Revised, Corrected, and Inlarged." Actually, though Rowland did translate Moffett's Latin work into English for the occasion, the only changes from the first editions of Topsell's two books are the use of smaller type, and the omission of several pictures and the foreword to Four-footed Beasts.

Topsell's books, the first major works on animals printed in Britain in English, came at the last moment that such a compendium of ancient belief, legend, and folklore concerning animals could have been published, since scientific knowledge about animals shortly swept away many of the old wives' tales contained in Topsell. Indeed, the pages of Topsell are crammed with bizarre information, and the bulk of it is presented with apparently complete confidence in its truth. For example, Topsell states that "if a woman take a Frog, and spit three times in her mouth, she shall not conceive with childe that year." In another place he affirms that "the horns of Unicorns . . . being beaten and drunk in water, doth wonderfully help against poyson." Elsewhere he tells how hunters in India capture the fleet tiger's cubs: 
The Hunters do devise certain round sphears of glass, wherein they picture their young ones very apparent to be seen by the dam, one of these they cast down before her at her approach, she looking upon it, is deluded, and thinketh that her young ones are inclosed therein, and the rather, because through the roundness thereof it is apt to rowl and stir at every touch, this she driveth along backwards to her den, and there breaketh it with her feet \& nails, and so seeing she that is deceived, returneth back again after the Hunters for her true Whelps; whilest they in the mean season are safely harbored in some house, or else gone on some shipboard.

Topsell may debate at some length questionable points such as the existence of a particular creature, but commonly he concludes, as he does in the case of dragons, "this which I have written, may be sufficient to satisfie any reasonable man, that there are winged Serpents and Dragons in the world."

Topsell presents also a sort of anthology of tales from Aristotle and Pliny, Solinus and the Physiologus, and dozens of writers duly named in the margins-tales about dogs fighting to the death for their masters, of elephants falling in love with women, of a dragon avenging the death of his human friend, of a lion persuading a woodsman to chop down the tree in which a bear which had killed the lion's cubs had taken refuge.

Except for a few additions, Topsell's information for The History of Four-footed Beasts and Serpents was, as Topsell notes on the title page, "Collected out of the Writing of Conradus Gesner." Conrad Gesner (1516-1565) was the German author of the popular sixteenthcentury Latin work Historiae Animalium, the starting point of modern zoology, which was published in six volumes at intervals from 1551 to 1587. One volume each was devoted to animals, amphibians, birds, fish, serpents, and insects. Most of Topsell's Four-footed Beasts came from Gesner's Volume I on animals, most of his History of Serpents came from Gesner's Volume V on serpents, and Moffett's Theatre of Insects was derived largely, though indirectly by way of Dr. Thomas Penny, from Gesner's final volume on insects.

Topsell followed Gesner, too, in the organization of his books. The modern zoological classification system had not yet been worked out, and the animals were listed, quite logically under the circumstances, in alphabetical order, Gesner according to their Latin names, Topsell according to their English ones. Topsell does do some grouping, however. For example, monkeys, baboons, and even satyrs and sphinxes are listed under the A's with Apes. Topsell has included over 160 ani- 
mals in all from "Antalope" to "Zibeth or Sivet-Cat" and some fifty serpents from "Adder" to "Viper," plus, interestingly enough, a few insects such as bees, earthworms, and spiders, derived, however, from Dr. Bonham rather than from Gesner. Topsell also includes several fabulous animals which are duly described and illustrated such as the dragon, mantichora, and unicorn.

Most of the animals, however, are actual creatures, though illustrations of them are sometimes unusual. For example, the camel in one picture appears gigantic in comparison with the man standing beside it, and the giraffe has long sharp horns. Descriptions of some animals' habits are also sometimes fantastic. For example, "when a Beaver is hunted and is in danger to be taken, she biteth off her own stones, knowing that for them only her life is sought"; "the Fox by laying his excrements in the Badgers den, getteth the same to his own use"; the Chameleon "never eateth meat, but is nourished with the winde, because it draweth in very eagerly many times the winde into the belly, whereby it swelleth"; and "when the Adder is thirsty and goeth to drink, she first of all at the water side casteth up her venom, lest that by drinking it descend into her bowels, and so destroy herself, but after that she hath drunk, she licketh it up again."

Topsell also follows Gesner in the organization of the material concerning each individual animal into eight categories: (1) the animal's name in several languages; (2) description of the animal and its habitat; (3) functioning of the animal's body and its diseases; (4) the animal's habits and instincts; (5) the utility of the animal to man; (6) use of the animal as food; (7) use of the animal as medicine; and (8) man's use of the animal in religion, poetry, proverbs, place-names, etc.

The numerous illustrative drawings, though not exact duplications, have clearly been derived from Gesner, except for a very few such as the drawings of the mantichora and the lion. Some drawings are realistic such as those of the deer, fox, and horse. Other drawings strike one as being heraldic (antelope and unicorn), stylized (rhinoceros), impressionistic (porcupine), or wholly imaginative (mantichora).

In its own time, the influence of Topsell's The History of Fourfooted Beasts and Serpents was limited to England because the continent already had the original Gesner in Latin and the Thierbuch, a German translation of the first four books of Gesner, published in $\mathbf{1 5 6 3 .}$ Today, Topsell's book is not only an exhaustive source of information about Elizabethan ideas on natural history but also, as the $1967 \mathrm{Da}$ Capo Press facsimile demonstrates, a quaint and fascinating book to read and to look at. It is, in short, what the title page says it is, a "His- 
tory of Four-footed Beasts and Serpents . . . interwoven with curious variety of Historical Narrations out of Scriptures, Fathers, Philosophers, Physicians, and Poets: Illustrated with divers Hieroglyphicks and Emblems, \&c. both pleasant and profitable for Students in all Faculties and Professions." 


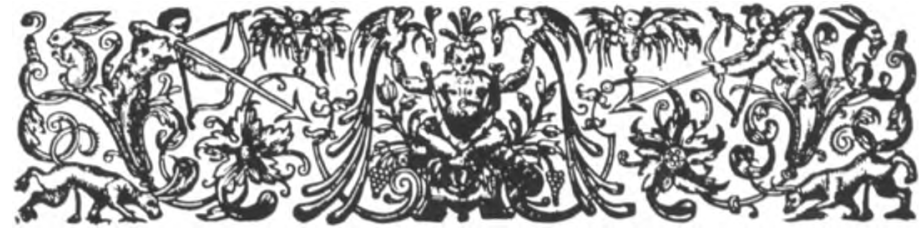

T H E

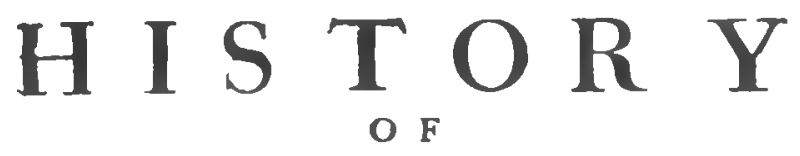

Four-Footed Bealts.

The ANTALOPE.
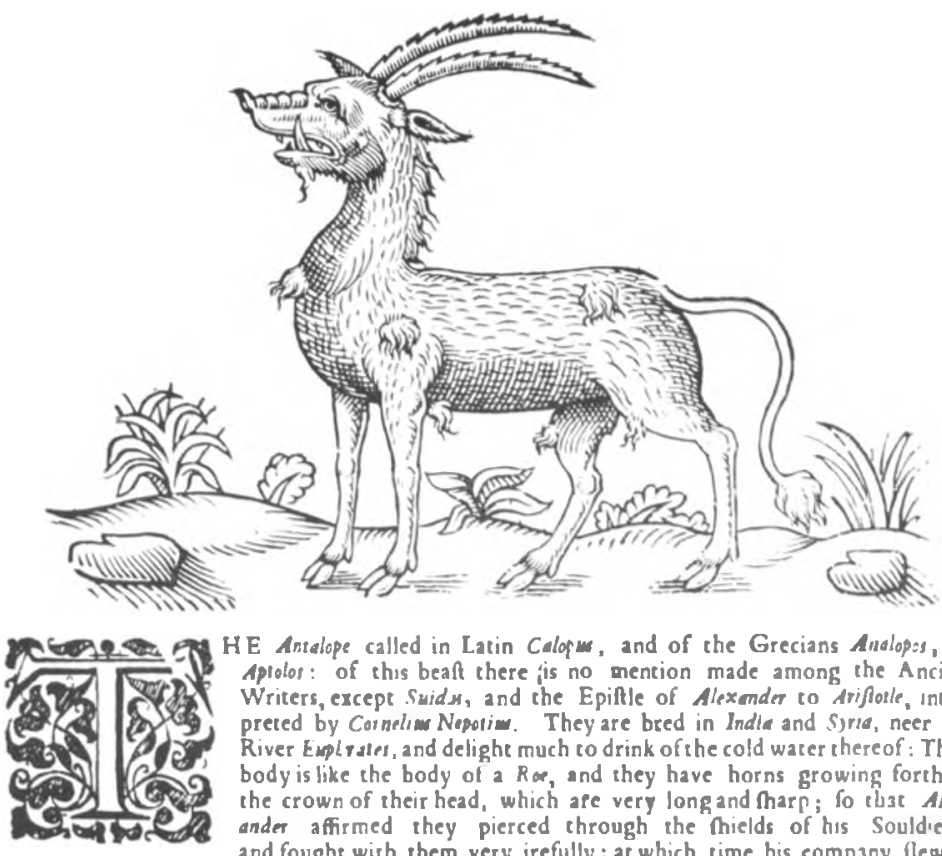

HE Antalope called in Latin Calorw, and of the Grecians Aludopes, or Aplolos: of this beaft there is no mention made among the Ancient Writers, except Saids, and the Epille of Alexmder to Arifosle, interpreted by Comblim Neporim. They are bred in India and Sjre, neer the Countrey of River Euphratel, and delight much co drink of the cold water there of: Th ir bred. body is like the body of $2 R$, and they have horns growing forth of the crown of their head, which afe very longand harp; fo tust Alex. ander affrmed they pierced through the Mields of his Soulders, and fought wirh them very irefully: at which time his company flew as he.travelled to India, eight thoufand five hundred and fifty; which great llaughter may be the occafion why they are fo rare, and feldom feen to this day, becaule thereby the breeders and means of their concinuance (which confilled in their multitude) were weakned and deltroyed. Their horns are great and made like a faw, and they with them can cut afunder the branches of Ofier or fmall trees, whereby it comerh to paffe that many tumes their necks are taken in the cwifts of the falling boughs, ;whereat the Beaft with repining cry, bewrayeth himliti to the Hunters, and fo is taken. The virtues of this Beaft is unknown, and therefore sivida faith, an An ralup; is but good in part.

First page of the text of Topsell's The History of Four-Footed Beasts, edition of 1658 . 